\title{
Peripheral visions? Rabi Island in Fiji's general election
}

\author{
Teresia K. Teaiwa
}

In a paper on Rabi and Kioa prepared for the Fiji Constitution Review Commission, I described both resettled groups as 'peripheral minority communities' in Fiji. Rabi Islanders, also known as Banabans, were resettled to Fiji in two major waves, the first in 1945 and the second in 1947. They were resettled because colonial and capitalist interests wanted to mine Banaba for phosphate without the encumbrances of a native population. Rabi Islanders became Fiji citizens at Fiji's Independence in 1970, and apart from a period in the mid-to-late 1970s when they featured in the media with their legal case against the British Phosphate Commissioners, they have maintained an enigmatically peripheral profile in the nation.

While focusing on the Rabi Island community's position in the 1999 general election, I am dealing with two major 'peripheralities': the way Rabi exists for the most part in the peripheral vision of the nation, and the way the nation occupies the periphery of Rabi Islanders' imagination. By choosing to describe something so central to the development of national consciousness as a general election from the marginal position of Rabi, I am seeking to bring both these peripheral visions to the centre.

This chapter is based partly on observations made over seven days (815 May) on the island of Rabi. During this time, the North Eastern General Communal Roll issued by the Elections Office was carefully studied, and interviews carried out using a four-page questionnaire, administered between 8-11 May. I did not administer any of my own questionnaires on the polling days, 12-13 May. The questionnaire could be described as investigating two broad areas: first, the level and sources of voter awareness on Rabi in relation to the new electoral system and national politics; and second, the range of cultural and political identifications held by Rabi Islanders. ${ }^{1}$ 
The average running time for an interview in English was thirty minutes, and between forty and fifty in Gilbertese. I had initially hoped to conduct about a hundred formal interviews while on the island, but due to the need for extensive translations from English into Gilbertese, and constraints of intra-island travel, only 33 formal interviews were carried out. ${ }^{2}$ Twentyfive interviews were carried out in Gilbertese, and the rest in English. Of the 25 interviews in Gilbertese, 11 were conducted with the assistance of interpreters and the rest were conducted unassisted.

All four villages: Tabwewa (6 interviews), Uma (5), Tabiang (13), and Buakonikai (9) were represented in the 33 interviews. Twenty of the interviewees were women and 13 were men. The slight over-representation of interviewees from Tabiang and of women, resulted from my position as 'researcher'. Because my family comes from Tabiang village, and since I stayed in our family home while on the island, I had more access to Tabiang villagers and my extended family. As a woman researcher, I found it easier to approach and talk with women; eleven of my interviews were conducted in the Women's Interest Centre at Nuku.

Although a quantitative breakdown of the survey results is presented in the Appendix, this research was not intended to produce definitive indicators. Rather, it should be seen, and is offered in this chapter, as an impressionistic representation of political consciousness on Rabi.

\section{Rabil Islanders as Banabans}

Many Fiji Islanders are uncertain about whether Rabi island is part of Fiji or not, and whether Rabi Islanders are Fiji citizens. Many people have asked me whether Rabi is in Kiribati, and whether Rabi Islanders have dual citizenship. Rabi Islanders are Fiji citizens who are entitled to a 'permanent residency' status if they entered Kiribati on a Fiji passport, because Banaba falls within the national boundaries of Kiribati. It bears repeating, though, that Rabi Islanders are Fiji citizens.

An added dimension to the peripheral perspectives I mentioned earlier, is my personal history as a Banaban/Rabi Islander. Born and raised neither on Banaba nor Rabi, I am a native speaker of English. Gilbertese is my second language. In the Gilbertese translation of my questionnaire, I unthinkingly substituted te tautaeka (the government) for 'the government of Fiji' in some of the questions. This translation sometimes caused interviewees to ask me for clarification, Te tautaeka $n$ ra? (Which government?) Of course, I was thinking and talking about the government of Fiji, but the need for clarification arose precisely because the government of Fiji is not the only government for Rabi Islanders.

Under the Banaban Settlement Act of 1970, ${ }^{3}$ amended in 1996, Rabi Islanders are administered by the Rabi Island Council, which is an elected body of Banabans representing each village. The history of the Rabi Island 
Council-beyond the scope of this chapter-has been filled with drama, intrigue, and pathos. ${ }^{4}$ For the present, it is enough to say that the Council is responsible for making and amending regulations on health, housing and social relations, levying taxes if necessary, and deciding on issues of development for the island and people. Te Kauntira, or the Council, is thus te tautaeka for Rabi Islanders.

As a fiercely democratic people, ${ }^{5}$ Banabans value consensus, especially if it has been reached through struggle and competition. For this reason, authority is always challenged and privilege rigorously contested in the community. Local politics thus loom very large in Rabi Islanders' consciousness. ${ }^{6}$ In a way, an event like the general election becomes an extension of local politics on Rabi. Furthermore, in the 1999 election, the Rabi Island Council did not publicly endorse any candidate, and Banabans were free to enjoy competition.

\section{Rabi Islanders as Fiji citizens}

When I asked interviewees whether they thought their community had contributed anything to the national good of Fiji, 8 were unsure and 24 responded in the affirmative. One respondent said Banabans contributed to the development of Fiji 'by developing Fiji'. Another respondent said, 'Yes, we contribute to the development of Fiji, but we don't remember how.' Others were more clear: 'We pay taxes, we work for the country'; 'We buy things'; 'Through agriculture and coconuts'. One respondent had a broad view: 'By teaching, working in government...I heard they contribute some money for the Fijians-we take part in Fijian functions and Banabans are friendly with Fijians'. Referring to Fijian provincial and Methodist church obligations, one respondent said, 'By giving soli to the province'. Another interviewee amplified this, saying, 'We've always contributed to different meetings in Taveuni and Suva'. Some respondents referred to contributions through phosphate (mined from the Banaban homeland) and phosphate monies (which add to Fiji's foreign exchange). So there was a diverse range of views among Rabi Islanders on how they contributed to the national good of Fiji. Some were unsure of their contributions-and this affects a community's relationship or identification with the nation.

Like other electors in Fiji, Rabi Islanders are entitled to two votes in a general election: a communal vote and an open vote. The two constituencies that include Rabi Island are the North Eastern General and the Cakaudrove West Open. The North Eastern General is geographically the largest of the three General Communal constituencies in Fiji. It includes Tailevu, Kadavu, Lomaiviti, Vanua Levu, Rabi, Taveuni, Kioa, and Lau. ${ }^{7}$ The Cakaudrove West Open includes Savusavu Bay, Natewa Bay, Buca Bay, and Rabi, but interestingly excludes the neighbouring island of Kioa which is, instead, part of the Lau/Taveuni/Rotuma Open Constituency. ${ }^{8}$ 
The North Eastern General Communal constituency should have had approximately 6,000 registered voters to share one third of the estimated 18,000 in the national total of the General Communal electorate. However, the supplementary roll of registered voters issued on 6 April 1999 showed that only 4,553 were registered as voters in the constituency, of whom an estimated 1,317 were Rabi Islanders, constituting 28.9 per cent or almost one third of the total constituency. ${ }^{9}$

The current total population of Rabi Island is about 4,000 . The number of voting age persons of Banaban descent living on Rabi Island and in other parts of Fiji is slightly higher than the registered 1,317. This is because some 600 of the total number of Banabans resident in Fiji (an estimated 300 of whom are of voting age) have yet to be confirmed as Fiji citizens. ${ }^{10}$ In fact, at polling stations during the elections, a significant number of people lined up to sign affidavits confirming their illegibility as voters to avoid the F\$50 fine for not voting.

\section{Rabil Islanders as 'others' and general electors}

At the last Fiji Census (1996), indigenous Fijians comprised 51 per cent of the total population, Indo-Fijians accounted for a little over 44 per cent, Rotumans 1 per cent, and 'Others' as they are so casually described, 4 per cent. As an ethnic category, 'Others' encompasses all non-Fijians and nonIndo-Fijians, including people of Pacific Islander descent, Europeans, 'partEuropeans ${ }^{\prime 11}$ and Chinese. Fiji's Pacific Islander community includes a number of groups, including Tongans, Samoans, Tuvaluans, Gilbertese, Banabans, Solomon Islanders and New Hebrideans (as they were known during the colonial period). ${ }^{12}$ Each community has its own history in Fiji; some settled here by choice, others did not. Indeed, as a group, 'Others' is a motley crew which has had widely differing fortunes in Fiji.

'Others' are also known as 'Generals' for electoral purposes. While the category of 'Generals' pre-existed 1987, the rise of political parties specifically for 'Generals' is a decidedly post-coup phenomenon. Before the 1992 general election, 'Others' and 'Generals' -indeed Fijians as well as Indo-Fijians-could (and did) join any political party they wished. ${ }^{13}$ But with the replacement of the racialist 1970 Constitution by a racist Constitution in 1990, ${ }^{14}$ the re-segregation of the nation's electorate produced explicitly race-based political parties which discouraged cross-ethnic political affiliation. While there seemed to be some political rationale for the emergence of two different Fijian parties, the SVT and the FAP, ${ }^{15}$ and the survival of the two pre-coup 'Indo-Fijian' parties, the NFP and the FLP, ${ }^{16}$ there were dubious grounds for uniting 'Generals' under party banners.

The General Voters Party and the General Electors Association had regional support as their main difference, with the GVP strongholds centred in the Central and Northern Divisions, and the General Electors Association 
drawing its support from the West. ${ }^{17}$ In 1998, the two parties explored unification, leading to the emergence of the United Generals Party. However, UGP was threatened with a revival of the GVP in 1999 as individual members not endorsed for seats broke away.

Rabi Islanders are significantly impacted by these so-called communal politics. Between 1970 and 1987, they had voted on the Fijian communal electoral roll. ${ }^{18}$ This was rationalised by the special circumstances of the islanders: having been resettled from their home island of Banaba to Fiji after the Second World War by the colonial government, purchasing the island on which they lived, and paying customary tribute to the paramount chief of their province, Cakaudrove. With the abrogation of the 1970 Constitution, and its replacement with the 1990 Constitution, Rabi Islanders (along with 'Melanesians') were shifted to the General Electoral Roll, thereby becoming a minority within a minority.

When asked how they felt about being on the General Electoral Roll, most of my respondents said they were satisfied with their position. Some of the responses were uncomplicated: 'Because that's what we are', and 'We're not Fijian'. Others elaborated: 'Because we're special, different,' 'Sometimes it's better not to be counted with Fijians,' 'We have no Fijian blood-we are Fijians by citizenship' and 'We're different from Fijians: they're native, we're not'. Most of the answers reflected Rabi Islanders' concern for indigenous Fijians. They were careful to acknowledge their difference from Fijians, thus rationalising their presence on the General Electors Roll. But none of them commented on what it meant to them to be grouped with part-Europeans, Europeans, Chinese and other islanders. This blind spot, I believe, indicates that many Rabi Islanders have not fully considered the complex cultural and political implications of their designation as General Electors. In being careful not to tread on Fijian toes, Rabi Islanders have not been able to strategise for skillful negotiating with other General Electors.

In the two post-coup elections before 1999, Rabi Island as part of one of the five General Communal constituencies, was represented in parliament by GVP candidate and shipping magnate, Leo Smith. ${ }^{19}$ GVP, of course, was then the coalition partner of the SVT. For Rabi Islanders, GVP's and Leo Smith's coalition with the SVT was highly desirable. Several levels of identification cemented the logic of Rabi Islanders' electoral representation by Leo Smith/GVP and SVT. Leo Smith comes from a Savusavu copra estate family he owns Consort Shipping Company whose vessel, the 'Spirit of Free Enterprise' (affectionately known by patrons as the SOFE), provides a direct service to Rabi Island at two crucial times of the year, ${ }^{20}$ and claims descent from the Tui Cakau, the paramount chief of Cakaudrove, under whose traditional protection Rabi Island falls. Smith's effectiveness in representing his constituency, however, was severely undercut by his 
appointment to the SVT cabinet between 1992-99. Having their MP in Cabinet did not alter Banabans' peripheral status vis-á-vis the nation.

In any event, Rabi Islanders would have felt secure under a SVT government, a party created by the Bose Levu Vakaturaga, and led by Sitiveni Rabuka, a kai-Cakaudrove, and the erstwhile hero of the 1987 coups (the goals of which most Rabi Islanders implicitly supported). ${ }^{21}$ Although Rabi Islanders, like most other Fiji citizens, had not previously had to cast a vote for or against Rabuka (because they were registered on non-Fijian rolls), the new electoral arrangements and Rabuka's decision to contest an open seat in the General Elections gave them this opportunity. For the first time, Rabi Islanders could elect a candidate who both could, and was likely to, become prime minister. Given this, in a sense then, they were not so peripheral.

\section{Rabi Islanders and voter awareness}

Q: Do you feel prepared to vote in this election?
A: Yes.
Q: Have you received any training or information on the new voting system?

A: No.

Q: Do you feel prepared to vote in this election?
A: Yes.
Q: Have you received any training or information on the new voting system?
A: Yes.
Q: Where did this training or information come from?

A: From Leo Smith's party.

Q: Please explain the voting system as you understand it.

A: We need to vote for Leo Smith because he's helped us already.

Q: Do you feel prepared to vote in this election?

A: Yes.

Q: Have you received any training or information on the new voting system?

A: Yes.

Q: Where did this training or information come from?

A: UGP.

Q: Please explain the voting system as you understand it.

A: Two voting papers-one for Vincent, one for Rabuka. I haven't seen a sample, so I don't know.

These three exchanges typify the range of responses I received. What became clear from my study was that while Banabans display a keen enthusiasm 
for exercising their political rights, they had an alarming lack of political education and information available to them before the election. So much so that of the 33 people I interviewed, 31 declared that they felt ready to vote in the election, but about half had not received any training or information on the new voting system. Of those who had, the overwhelming majority had done so from party officials and their campaign literature. None of the people I spoke to gave any indication that they had received information on the new voting system from the Fiji Elections Office. The Elections Office's educational campaign covered television, radio and print media, and some community visits and workshops. Television access in Rabi is limited by the lack of electricity on the island; the clearest radio transmissions come from the Island Network's Fijian language station (and, ironically, Tonga and Kiribati national radio); and the national daily newspapers are not delivered to the island regularly.

Most interviewees obtained the bulk of their understanding about the elections from party officials, candidates in-person, and word-of-mouth. Given this situation -where the transmission of information and education still depends on interpersonal communication rather than technologyRabi Islanders would have benefitted greatly from an impartial presentation by the Elections Office..$^{22}$ As it was, many who relied on political parties for information were not told about their voting options. Very few people I spoke to could describe accurately the new voting system, and a significant number expressed surprise upon hearing that there was a new voting system at all. When asked to explain the voting system as they understood it, these are some of the things the interviewees said.

'I accept the coalition system that's been given to us.'

'There are two voting papers. Two sides.'

'I will vote above the line after checking for my name at the polling station.'

'Give a big tick. Two votes.'

In many instances, I found myself having to explain the new system to my interviewees. Because of the newness of the information, most interviewees were unable to answer this question: 'In the new voting system, which alternative do you think is better?' Of the few who did feel confident answering the question, five thought voting below the line was a better option, while eight preferred the above the line option, and two described them as equally good options. Some of those who expressed a preference for voting below the line gave the following reasons.

'Because it's my choice.'

'You can see their (the candidates') names.'

'Because that's what the preferential system is all about.' 
Those who thought that voting above the line made more sense, had explanations like this

'It's the easier method for everyone, including old people.'

'Above the line is okay, especially if you don't know the candidates.'

'I trust the party.'

'Because I'm not sure my choices below the line will be good.'

While there are some convincing arguments for above-the-line voting, (for example, it produces a government, not just a parliament), what abovethe-line voting also does is encourage peripheral communities like Rabi to abdicate their right and shirk their responsibility to understand and actively engage in national politics. Rabi Islanders were seriously under-educated (though not necessarily unprepared) for the 1999 General Elections, and were probably not the only community in this situation.

If most Rabi Islanders got what little information they had from political parties, which parties were they? Although Rabuka had visited the island (in fact, he only went to the administrative center at Nuku, and not to the villages) on the eve of the elections, he was so confident of the Rabi vote that he did not return. SVT's campaign on Rabi rode for the most part on the backs of UGP and GVP campaigns. None of the predominantly IndoFijian political parties campaigned on the island, mainly because there were no Indo-Fijian candidates running for the Cakaudrove West Open seat. The NFP and Labour parties have practically non-existent profiles on Rabi. However, apart from FAP, there did not seem to be any overt campaigning on the island by other Fijian parties either.

The two parties campaigning most vigorously on Rabi were UGP and the GVP; FAP had a modest following and COIN had fleeting visibility. The candidate for UGP was Vincent Lobendahn, GVP had the incumbent Leo Smith, FAP's candidate was Edward Daniel Reece, and COIN had Tony Fong. All four men had campaigned on the island, but during polling week, only three of them were physically present on the island (Lobendahn, Smith and Reece). ${ }^{23}$ Interestingly, while most campaign material was in English, Leo Smith's campaign poster was the only one which utilised the Gilbertese language (see appendix). The only contest of any significance was between Lobendahn and Smith. Although Smith had the advantage of incumbency with the Rabi constituency, his defection from the UGP several months before the election, and the UGP's coalition with the ruling SVT, legitimised Lobendahn's campaign to a great extent. This General conflict had specific implications for the Rabi Islander electorate.

When asked to describe the various aspects of candidates' campaigns which had made an impression on them, these were some of the responses from interviewees. 
'We've been with this party (GVP) a long time with no progress.' '(The UGP candidate explained that) they are already in parliament. We select two people to stand for us: one from SVT, one from UGP.' '(The UGP candidate said) we'll vote for the party, and we'll be represented directly in government. If an independent candidate goes in, he'll have to go beg the government for me.'

'(The 'GVP' candidate) took power to us; he try to frighten us to vote.' '(They say they're) trying to help the people here.'

'(They say we need) a change in government; (they talk about) corruption.'

'(The UGP candidate) said that the government put up this Constitution to include us...(that) the Rabuka government is experienced. (The candidate said) he's introducing self-help projects like seaweed and specialised fisheries for buyers like Joe's Farm...(and that he'd be) improving the hospital and wharf.' 'Leo didn't make any promises. They all criticised each other. So I just pray that when I go into the polling booth I'll know who to vote for.' 'Leo talked about the things he' d done-(improving) water, the hospital-(he also said) the launch would come to Uma. Reece talked about change.'

'Leo and the Tui Tunuloa were scaring us by saying that they' $\mathrm{d}$ close the reef if we don't vote the way they want us to.'

'It doesn't matter (what others say) because I'll stay on Leo's side.' '(The COIN candidate) said that our children and grandchildren's future would be well looked after by him...(but) his stay was very short, and (he) didn't say much.'

These answers present a complex picture of some of the concerns Rabi Islanders had while facing this election. Issues of significance to the islanders included: direct representation in government and improvements to the quality of life on the island. Such interests would seem to not differ greatly from other communities in Fiji.

\section{A Rabil Island forecast}

On polling days on Rabi, the candidates and their parties set up their bases around the polling station. I visited the polling station at Tabiang on Wednesday 12 May and the Nuku polling station on Thursday 13 May. At both places, Reece's support, though strong, was clearly not as great as the support for his two major competitors. At Tabiang, Smith and Lobendahn seemed to have about equal numbers of supporters in their 'sheds,' while at Nuku, Lobendahn appeared to have the edge. Of course, the politics of 'sheds' as indicators of support is complicated. In spite of the cultural value 
given to competition, island etiquette dictates fair-play: an empty shed would delegitimise the whole contest. And so, as I observed, in some cases families would agree to send some of their members to one candidate's shed, while others would go to another's. Given the (ideal) secrecy of the ballot, though, the sheds are ultimately unreliable indicators-not to mention the questionable propriety of the policy which allows them to be erected in the first place.

Of the people I interviewed, 13 thought that SVT and its coalition partners would win the election, 1 expressed faith in the FAP and its coalition partners, and 19 declined to answer the question. Seventeen respondents thought Rabuka would be returned as Prime Minister of Fiji, 3 predicted Adi Kuini for the post, 1 said she was not sure, and 12 offered no answer. If we read the silent majority as an affirmation of the status quo, then it would seem that Rabi Islanders were to a large extent expecting that SVT and its coalition partners to win the election, and Rabuka returned as prime minister. As it turned out, of course, neither was to be. The SVT captured only 8 seats, NFP none, and the UGP only two. The Labour/ FAP/PANU 'People's Coalition' won the majority of seats in parliament, and Mahendra Chaudhry became the first Indo-Fijian Prime Minister of Fiji.

\section{Election results and results of results}

In the Cakaudrove West Open Constituency, Sitiveni Rabuka won easily. Of a total of 14,066 votes cast, Rabuka polled 9,190, (2,618 more than the required majority of 6,572), and 69.92 per cent of vote. His nearest contender, Aisake Kubuabola of the VLV polled 1,936 votes or 14.73 per cent. In the Northeastern General Communal Constituency, Leo Smith won on the fourth preference. On first preferences, Smith had polled 1,305 votes. Vincent Lobendahn had been leading on first preferences with 1,636 votes. However, this was 152 votes short of the required majority (of fifty per cent plus one). All of Lobendahn's four rivals had given him and the UGP their fifth preference, while Leo Smith had received the fourth preferences of COIN, FAP, and Ian Simpson. Leo Smith ended up winning the seat with 1,879 votes, leaving Lobendahn behind with 1694 votes. ${ }^{24}$ Significantly, the Northeastern General Constituency had 287 invalid ballot papers. We cannot know what percentage of those invalid votes were from Rabi. However, even if all the invalid votes came from Rabi, it would still indicate that the majority of the islanders were fairly well prepared for the new voting procedures.

What did the outcome of the election mean for Rabi? Having returned Rabuka to parliament, they lost him when unexpectedly, before the first sitting of the newly elected parliament of 1999, he resigned his seat to become the chair of the Bose Levu Vakaturaga. When the new parliament 
convened on June 15 1999, the open constituency of Cakaudrove West was not represented. ${ }^{25}$ It was, however, represented by Leo Smith, the member for the Northeastern General Communal Constituency, who had campaigned as an independent under the unofficial banner of GVP, and in an unofficial coalition with SVT. Before parliament convened, though, Smith and his GVP colleague, Bill Aull, joined the government coalition. In this sense, the words of one of my interviewees takes on new meaning

'...If an independent candidate goes in, he'll have to go beg the government for me.'

Smith, the 'Independent' MP, made an unorthodox, but perhaps necessary move given the paradigm-shifting results of the 1999 General Election. Rabi is now represented by a government backbencher, though it is hardly the government they expected to get.

\section{Peripheral visions?}

My research and analysis of Rabi Islanders and the Fiji General Elections of 1999, pulls towards reassessing my initial description of the community as peripheral. Although I suspect that the welfare of our community is not high on the agenda of the present government, we can only hope that our representatives in parliament will indeed be advocates of our minority interests. But being a minority does not necessarily mean we have to be peripheral. European, part-European and Chinese interests are minority interests without being peripheral. Like other rural communities, Rabi Islanders will always be geographically peripheral in Fiji, but that does not necessarily translate into political or cultural peripherality. Whether Rabi Islanders are effectively represented or empowered in Fiji's national politics might be instructively illuminated by a different elections process.

On Saturday 28 August 1999, a young woman named Joanne Terubea ${ }^{26}$ was crowned Miss Hibiscus, the premier beauty pageant title in Fiji, and, I contend, an important indicator of racial and cultural politics in Fiji. Hailed as the first Banaban Miss Hibiscus by the media (see Fiji Times and Daily Post 29 August 1999), it does indeed seem that Fiji is ready, at least at the level of popular culture, to embrace Rabi Islanders in the national imaginary. Indeed, in her press statements, Joanne has been careful to insist that she is a Fiji Islander first and foremost.

\section{Notes}

1 Although both sets of questions will be discussed in this chapter, this same survey is also being used as the primary source material for another paper, more explicitly dealing with the issue of minority rights. 
2 This sample amounts to roughly 3 per cent of the total electorate on Rabi. Though this is, in objective terms, a small proportion of the community, it is fairly representative in its distribution.

3 From my survey, only 8 out of 33 respondents had actually ever read the Banaban Settlement Act. By comparison, only 6 out of the 33 said that they had read the Fiji Constitution.

4 See the Aidney Report (Aidney et al. 1994) for an inventory of financial mismanagement by successive Councils which culminated in a 'coup' of sorts when Rabi Islanders overthrew an elected council in 1991.

5 Grimble and Maude (see Maude 1989) have irresponsibly tried to inscribe a chiefly or hierarchical system on Banabans, but except for those few families who are privileged by Grimble and Maude's records, the majority of Banabans maintain that they did not and do not have a chiefly system. Rather, each family or clan has a role to play which integral to the whole of the society. This is similar to other island traditions in Kiribati, especially Tabiteuea, whose name announces its democratic belief system: e tabu te uea. This may be translated to mean that either a) no chiefs are allowed; or b) everyone is a chief.

6 In a forthcoming article to be published by the International Working Group for Indigenous Affairs, my sister, Katerina Teaiwa describes the way that Banabans refer to Rabi as abara-meaning not only our land, but our country.

7 The 1999 General Election candidates in this constituency included (in alphabetical order) Anthony Fong (COIN), Vincent Lobendahn (UGP), Edward Daniel Reece (FAP), Ian Mitchell Simpson (Independent), and Leo Smith (Independent/GVP). Other parties which listed preferences in this constituency were FLP, VLV and NVTLP.

8 The 1999 General Election candidates in this constituency included (in alphabetical order) Mosese Gere (Na Vanua Tako Lavo Party), Aisake Kubuabola (VLV), Epeli Ligamamada (FAP), and Sitiveni Rabuka (SVT). Other parties which listed preferences in this constituency were UGP, NFP, COIN, and FLP.

9 Banaban statistics are not normally disaggregated from 'Other' indicators and statistics in Fiji. This makes acquiring information about Banabans from nationallycollected data quite difficult to obtain. The total number of Rabi Islanders registered in the North Eastern General Communal constituency was arrived at by a careful survey of the Electoral Roll, identifying Banaban names (as opposed to Gilbertese or Kioan names), and place of residency. A certain margin of error must be allowed for this method which yielded these approximate figures: 1,171 Rabi Islanders onisland; 146 Rabi Islanders off-island (but still within the same constituency). The Elections office, however, expected a total of only 1033 ballot papers to be cast on Rabi.

10 My father's brother, who was born in Kiribati and came to Fiji as an infant, and has lived here all his life, was unable to register to vote because he was told he was not yet a Fiji citizen-even though he has lived in Fiji for 52 years. Several hundred Banabans are in similar situations. The Immigration Department is requiring these people to pay $\mathrm{F} \$ 800$ fees to become Fiji citizens, which seems unfair and unreasonable to many Banabans. The Rabi Island Council is seeking alternative avenues for confirming all Banabans as Fiji citizens. 
11 Fiji is the only country I know of which uses the term 'part-European' to describe people of mixed European and Pacific Islander descent. Common in Native American usage is the term 'mixed-blood' or metis; in Latin America and the Caribbean the terms criollo and mestizo are used. In Hawaii, people of mixed descent are described as hapa or hapa-haole; in Samoa they are described as afakasi, in francophone Tahiti as demi. While the term 'half-caste' is sometimes used colloquially in Fiji, only 'part-European' appears on bureaucratic forms as a subsection of the category 'Others'.

12 The New Hebrides became the independent nation state of Vanuatu in 1980, and the people of Vanuatu are called ni-Vanuatu.

13 An Independent Candidate in the 1999 general elections, Arthur Jennings was a National Federation Party candidate in the late 70 s or early 80 s. However, most 'Generals' (like Charles Walker, the Stinsons, John Falvey, Ted Beddoes, Fred Caine, et al.) tended to make their home through the General Electors Association within the governing Alliance Party headed by Ratu Sir Kamisese Mara. (The Alliance comprised three groups: the General Electors Association, the Fijian Association, and the Indian Alliance.)

14 I make the distinction here between 'racialist' and 'racist' though some may argue that there is no difference or that any form of racialism is inherently racist. However, the 1970 Constitution of Fiji was not forged in quite the same overtly racist spirit in which the 1990 Constitution was. Although the 1970 Constitution of Fiji inscribed race-based electoral politics ( 12 communal seats each for Fijians and Indians, and 3 communal seats for Generals), it also provided for multicultural or inter-communal identifications (10 seats each for Indian and Fijian candidates on a national roll, and 5 'national' seats for Generals). The 1990 Constitution, however, did away with open seats altogether, and radically decreased the proportion of Indian seats in parliament (in a parliament of 70, Fijians held 37 seats while Indians had 27 and Generals held 5).

15 The SVT was set up in 1990 by the Great Council of Chiefs or Bose Levu Vakaturaga to contest the 1992 elections (its contenders then were the Fijian Nationalist Party headed by Sakeasi Butadroka, and the Western-based ANC headed by Apisai Tora); the Fijian Association Party emerged in 1993 as part of a dissident group of former SVT supporters led by the late Josefata Kamikamica (see the Fiji Times 7 August 1999 for an interesting letter to the editor which provides a genealogy of mainstream Fijian political parties).

16 While the NFP claims roots in the cane-belt, it has, over the years, become increasingly identified as the party of Indo-Fijian business and the professional class; the Labour Party, on the other hand, is solidly identified with both rural and urban Indo-Fijian working classes and has loyal support from a small multicultural urban working class and segments of the intelligentsia.

17 The GEA, which formed to contest the 1994 election, drew its membership from the ANC (led by the ubiquitous Apisai Tora) which had contested the 1992 election. The leadership of both of the 'Generals' parties has tended to come from Europeans and 'part-Europeans.' All elected 'Generals' in 1992 and 1994 were 'part-Europeans' (David Pickering, Bill Aull, Leo Smith, Harold Powell, Vincent Lobendahn). Attempts to increase support across their traditional borders have often taken the 
form of unscrupulous bribing and herding of Melanesian and Micronesian voters to rallies and polling stations.

In addition to regional differences, however, there do seem to be cross-cutting issues of class and culture determining the political factioning of 'Generals.' For instance, the symbolic (though not formal) resurrection of the General Voters Party in the 1999 Elections, under the leadership of the late Phillip King, Fred Caine, and Peter Howard in support of successful independent candidates Bill Aull (Central General Constituency) and Leo Smith (Northeastern General Constituency). In the Central General Constituency, Bill Aull's campaign was identified as solidly working class and subtly Polynesian or islander-oriented. His main rival, Robin Storck, of the United Generals Party, on the other hand, was identified with European and business interests. Leo Smith is the owner of Consort Shipping, and very rarely identified with working class interests, his alignment with the 'GVP' group thus was pragmatic.

18 A history of Rabi Islanders' electoral representation in Fiji between 1970 and 1987, would greatly illuminate the manner in which different communal interests were expressed and investments or disinvestments made in the Rabi Island community. This, however, is beyond the scope of this chapter. Forthcoming work by my sister, Katerina Teaiwa, will shed more light on this time period.

19 In 1992 Rabi Islander, Teiwaki Benaia (ANC) and Gus Billings (Independent) ran against Leo Smith. While Teiwaki's genealogy (being the grandson of the Reverend Tebuke Rotan, for many years the Chairman of the Rabi Island Council) might have carried a lot of weight with other Rabi Islanders, he was not able to pull in voters from other parts of the Northern General Constituency.

20 Otherwise, getting to Rabi from Suva involves an inter-island ( 40 minute) plane or (overnight) boat trip to Savusavu, a (21/2 hour) car or ( 4 hour) bus ride to Karoko landing, and a ( $1 / 2$ hour) punt ride to Rabi. The cost of a direct and one-way trip from Suva to Rabi on the SOFE is about F $\$ 50$. By plane and taxi from Suva a one way trip costs $F \$ 210$. By boat to Savusavu and bus to Karoko it costs $F \$ 80$. A direct flight service to Rabi Island has been proposed by Air Fiji to be launched in 1999. The cost of a one way ticket has been set at F\$120. The high cost of interisland travel contributes greatly to Rabi Islanders' isolation.

21 I recently heard about a fantastic rumour which had been spread among some Rabi Islanders after the coup that the Australian government was willing to evacuate Banabans to Australia!

22 In a presentation to the Citizens' Constitutional Forum Elections Audit 17/7/99, Elections Office Information Officer, Suzie Naisara-Grey admitted that her office had indeed neglected Rabi while offering workshops in other communities in the General electorate like the Suva-based Chinese Association. Naisara-Grey's statement is ironic when we remember that her father, the late Jone Naisara, was a representative of Cakaudrove (and Rabi Island) in pre-coup parliaments.

23 COIN's Tony Fong's absence during polling week was noticeable. He had declared in the COIN brochure that one of his main ambitions was to find a wife of either Rabian or Kioan descent, but apparently, when he had come to campaign he only spent an hour in total on the island! 
Significantly, Lobendahn came to the island alone, and relied completely on a local Rabi Islander support-system. Leo Smith arrived on the island with an entourage of Gilbertese and some Rabi Islanders drawn from the Savusavu area. Daniel Reece came to the island accompanied by a Fijian woman who spoke fluent Gilbertese.

24 It would be interesting but impossible to find out where exactly within the constituency Smith picked up his slim majority of 185 . Detailed information from the Elections Office regarding ballots from Rabi will not be available-ballots from individual polling stations are placed into a common bin so as to preserve their secrecy, and make it impossible to identify localised voting patterns within a constituency.

25 A by-election was to be held in September 1999 with a new VLV candidate standing: Ratu Epeli Ganilau. This, of course, raises a whole new set of cultural and political issues for the Cakaudrove West Open Constituency-which unfortunately, cannot be analysed here!

26 Being the daughter of Reverend Rongorongo Terubea, the Chairman of the Rabi Island Council who was deposed in a popular uprising on the island in 1991, complicates the local reception of Joanne's crowning as Miss Hibiscus. 


\section{Appendix-Breakdown of survey results}

\begin{tabular}{lllll} 
Village & & \multicolumn{2}{c}{ Party affiliation } & Male (13) \\
Tabwewa & $(6)$ & UGP & $(9)$ & Female (20) \\
Uma & $(5)$ & GVP & $(2)$ & \\
Tabiang & $(13)$ & None & $(22)$ &
\end{tabular}

Buakonikai (9)

Age

Religion

Education

$21-30 \quad(3)$

$31-40 \quad(11)$

Catholic (13)

Methodist (13)

Primary

Secondary (12)

$41-50 \quad(10)$

Other

Tertiary

$51-60$

Unstated

(7)

(7)

1. Do you feel prepared to vote in this election?

Yes: 31 No: 1 No response: 1

2. Have you received any training or information on the new voting system?

Yes: 16 No: 15 No response: 1

2a. Where did this training or information come from?

Political party: 15

Elections office: 0

Other: 0

2c. In the new voting system, which alternative do you think is better?

Below the line: 5 Above the line: $8 \quad$ Both: 2

3. Have you been visited by any candidates for this election?

Yes: 17 No: 13

One candidate or representative: 5 (UGP)

Two candidates or representatives: 3 (UGP and "GVP")

3-4 candidates or representatives: 6 (UGP, GVP, FAP, COIN)

More candidates or representatives: 1

3c. Do you feel you have a good choice of candidates in your constituency?

Yes: 27 No: 4

$3 d$. What factors influence your opinion most? Please rank in order of priority

$\begin{array}{ll}\text { experience } \# 1 & (18+3 \# 3 \text { ranking) } \\ \text { race } & \# 5 \\ \text { reputation } & \# 8 \\ \text { wealth } & \text { unranked } \\ \text { personality } & \# 7 \\ \text { religion } & \# 6 \\ \text { speaking ability } & \# 4 \\ \text { education } & \# 2(10+5 \# 1 \text { ranking }+5 \# 3 \text { ranking) } \\ \text { work habits } & \# 3(7+1 \# 1 \text { ranking }+5 \# 2 \text { ranking) } \\ \text { gender } & \# 8\end{array}$

4. What is your main source of news on the election campaigns? Please rank in order of accessibility.
a. radio
$\# 3(4 \# 1+2 \# 2)$
b. newspapers
$\# 2(7 \# 1+1 \# 2)$
c. party manifestos, brochures
$\# 1(16 \# 1+3 \# 2+1 \# 3)$
d. Elections Office literature
$\# 4(1 \# 1+2 \# 2+1 \# 3)$
e. candidates in-person
$\# 2(3 \# 1+6 \# 2+2 \# 3)$
f. your own travels to town or
city centres
unranked
g. word-of-mouth
$\# 3(1 \# 1+4 \# 2+5 \# 3)$

5. Are you happy with Banabans' inclusion on the General Electors roll? Yes: 25 No: 4

6. Have you ever read the Constitution of Fiji?
Yes: 6 No: 27
6.i. 1970
6.ii. 1990 
6a. Have you received any training or information about the 1997 Constitutional Amendment? Yes: 1 No: 32

6b. Where did this training or information come from?

The Citizens' Constitutional Forum-'Your Constitution, Your Rights' handbook

7. Have you ever read the Banaban Settlement Act?

Yes: 8 No: 25

7.i. 1970

7.ii. 1996 Amendment

7a. How did you get access to the Act?

From the Rabi Council of Leaders

From the Rabi Community Library

A personal copy

7b. What caused you to read the Act?

Work related

Personal interest

Educational

8. In your opinion, do Banabans contribute to the national good of Fiji? Yes: 24 No: 8 Unsure: 1

9. Is being a citizen of Fiji important to you? Yes: 32 No: 1

9b. Can you sing the national anthem of Fiji?

Yes: 30 No: 3

$9 \mathrm{c}$. On what occasions do you commemorate or celebrate your citizenship in this country?

October 10th

December 15 th

9d. Which of the languages spoken in Fiji are you fluent or conversant in?

$\begin{array}{ll}\text { English } & \# 1(30) \\ \text { Fijian } & \# 1(30) \\ \text { Hindustani } & \# 2(5) \\ \text { Rotuman } & \# 3(1) \\ \text { Tuvaluan } & \# 2(5) \\ \text { Chinese } & \text { unranked }\end{array}$

9e. Does being a citizen of Fiji make you feel you have a bond with all Fiji Islanders?

Yes: 10 No: 1 No response: 22

9e.i. Which ethnic group of Fiji Islanders do you feel closest to? Please rank:

Fijians

Indo-Fijians \#6

Rotumans \#5

Europeans \#5

Part-Europeans \#4

Chinese unranked

Gilbertese $\quad \# 2(10 \# 1+14 \# 2+2 \# 3)$

Kioans \#3(2\#2+12\#3)

10a. Which parties do you predict will form the next government of Fiji?

SVT: 13 Other: 1 No response: 19

10a.I. Do you think the voting system will greatly affect who wins the election?

Yes: 5 No: 1 No response: 27

10a.ii. Do you prefer the new voting system or the old one? New: $8 \quad$ Old: 7 No response: 18

10c. Who do you predict will be the next Prime Minister of Fiji?

Rabuka: 17 Adi Kuini: 3 Undecided: 1 No response: 12 